J. Clin. Chem. Clin. Biochem.

Vol. 15,1977 , pp. 69-75

\title{
Simultaneous Radioimmunoassay for Corticosterone and Deoxycortisol in Human Serum: Sex Differences in the Mean Serum Concentrations ${ }^{1}$ )
}

\author{
By M. Schöneshöfer, Helga Harendt
}

Division of Endocrinology, Department of Internal Medicine, Klinikum Steglitz, Freie Universität Berlin

and $P$. Vecsei

Institute of Pharmacology, Universität Heidelberg

(Received May 8/September 2, 1976)

Summary: A specific radioimmunoassay is described which allows the simultaneous determination of serum corticosterone and deoxycortisol. The method involves extraction with dichloromethane, purification by paper chromatography in a modified Bush-system and quantitation by radioimmunoassay. The normal serum concentration of both steroids were found to be dependent on sex and menstrual cycle. Mean concentrations ( $\pm S$. D.) in males, females (follicular phase) and females (luteal phase) were $4210 \pm 2170 \mathrm{ng} / 1,2410+1480 \mathrm{ng} / \mathrm{l}$ and $4390 \pm 2320 \mathrm{ng} / \mathrm{l}$ for corticosterone and $499 \pm 273 \mathrm{ng} / \mathrm{l}, 207 \pm 152 \mathrm{ng} / \mathrm{l}$ and $335 \pm 182 \mathrm{ng} / \mathrm{l}$ for deoxycortisol.

After adrenal stimulation by corticotropin itself or by insulin induced hypoglycemia, the serum concentrations of corticosterone became significantly higher than those of deoxycortisol. After oral administration of dexamethasone serum concentrations of both steroids were suppressed to levels below the limit of the normal range. One hour after oral metyrapone administration at midnight, serum corticosterone decreased, while serum deoxycortisol increased by a factor of about five. After eight hours serum concentrations of both steroids were increased considerably. Corticosterone attained levels slightly higher than the normal range and deoxycortisol rose to levels which were higher than the normal mean concentrations by a factor of about 500 .

\section{Simultaner Radioimmunoassay für Corticosteron und Desoxycortisol in Humanserum: Geschlechtsdifferenzen der mittleren Konzentration im Serum}

Zusammenfassung: Es wird ein spezifischer Radioimmunoassay beschrieben, der die simultane Bestimmung von Corticosterön und Desoxycortisol im menschlichen Serum ermöglicht. Die einzelnen methodischen Schritte bestehen aus einer Extraktion mit Methylenchlorid, einer papierchromatographischen Reinigung in einem modifizierten BushSystem, sowie der quantitativen, radioimmunologischen Bestimmung. Die normalen Serumkonzentrationen beider Steroide sind abhängig vom Geschlecht und Menstruationszykluṣ. Die Normalwerte für Männer, Frauen in der follikulären Phase und Frauen in der lutealen Phase betragen $4210 \pm 2170 \mathrm{ng} / \mathrm{l}, 2410 \pm 1480 \mathrm{ng} / \mathrm{l}$ und $4390 \pm 2320 \mathrm{ng} / \mathrm{l}$ fur Corticosteron und $499 \pm 273 \mathrm{ng} / \mathrm{l}, 207 \pm 152 \mathrm{ng} / \mathrm{l}$ und $335 \pm 182 \mathrm{ng} / \mathrm{l}$ für Desoxycortisol. Nach Stimulierung der Nebenniereñrinde dưrch Corticotropin oder insulininduzierte Hypoglykämie stiegen die Serumkonzentrationen von Cortiçosteron signifikant höher als die von Deșoxycortisol. Nach oraler Gabe von Dexamethason wurden die Serumkonzentrationen beider Hormone auf ein Niveau supprimiert, das weit unterhalb des Normalbereiches lag. Eine Stunde nach oraler Gabe von Metopiron um Mitternacht fiel die Serumkonzentration von Corticosteron ab, während die von Desoxycortisol um einen Faktor von etwa 5 anstieg. Nach 8 Stunden waren die Serumkonzentrationen beider Steroide beträchtlich angestiegen. Corticosteron erreichte Konzentrationsspiegel, die leicht über dem Normalwert lagen. Dexoxycortisol stieg an bis auf Werte, die um den Faktor von etwa 500 über dem Normalwert lagen.

1) Supported by Deutsche Forschungsgemeinschaft. 


\section{Introduction}

Over the past few years several methods allowing the simultaneous determination of adrenal steroids have been published. The advantages of a simultaneous estimation of steroids for clinical purposes have been discussed elsewhere (1-4). In all the methods using competitive protein binding techniques as a final quantitation step, steroids have to be separated from the majority of other compounds prior to the radioimmunoassay. Methods for the separation of corticosterone and deoxycortisol reported hitherto are limited to thin-layer (4) or LH-20-Sephadex column chromatography (2). Separation of these two steroids by paper chromatography has not yet been reported.

Mean plasma concentrations of corticosterone and especially of deoxycortisol in normal subjects exhibit a considerable range of variability (range for corticosterone: 4-10 $\mu \mathrm{g} / \mathrm{l}$; range for deoxycortisol: $0.6-10$ $\mu \mathrm{g} / \mathrm{l})$. Little information is available concerning the sex differences of these two steroid hormones. In the present paper a sensitive and specific radioimmunoassay for corticosterone and deoxycortisol is described using paper chromatography as separation technique. Furthermore, we report the normal ranges, sex differences and changes after adrenal stimulation and suppression, for the serum concentrations of both steroids.

\section{Materials and Methods}

\section{Solvents and reagents}

Analytical grade chemicals were used throughout. Two-fold distilled water, benzene, n-hexane and methanol were purified by charcoal extraction. Borate buffer (pH 8) containing $20 \mathrm{~g} / 1$ ethylene glycol and $6 \mathrm{~g} / \mathrm{l}$ human $\gamma$-globulin (Kabi) was used for incubation. Dextran (Dextran-70, Pharmacia, Upsala) and Norit A (Serva, Heidelberg) were used for the separation procedure. The scintillation mixture "Insta Gel" was supplied from Packard Instruments. Tritium was measured in a liquid scintillation spectrometer (Packard Instruments, model 3385).

Pipettes and counting vials were of the disposable type. Semiautomatic Hamilton syringes were used for the assay pipetting procedures. Conical extraction tubes were washed with diluted detergent for several hours and thoroughly rinsed with distilled water, followed by two washings with dichloromethane. Whatman2-paper strips were extracted chromatographically with methanol for at least 24 hours.

The unlabelled corticosterone (21, 11-dihydroxy-4-pregnene-3, 20-dione) and deoxycortisol (21, 17-dihydroxy-4-pregnene-3, 20-dione) were purchased from E. Merck (Darmstadt). $\left[{ }^{3} \mathbf{H}\right]-$ corticosterone (S. A. $54 \mathrm{Ci} / \mathrm{mmol}$ ) and $\left[{ }^{3} \mathrm{H}\right]$ deoxycortisol (S. A. $43 \mathrm{Ci} / \mathrm{mmol}$ ) were obtained from New England Nuclear Corporation. Steroid standards were dissolved in ethanol and stored at $-20^{\circ} \mathrm{C}$. The labelled steroids were purified by paper chromatography fortnightly, dissolved in ethanol and stored at $4{ }^{\circ} \mathrm{C}$.

Antisera for corticosterone and deoxycortisol were raised in rabbits, immunized with corticosterone- and deoxycortisol-21hemisuccinate-bovine serum albumin conjugate, respectively (5).

The final antiserum dilutions (in $0.4 \mathrm{ml}$ ) were 1:30 000 for the corticosterone assay and 1:100 000 for the deoxycortisol assay.

\section{Sample preparation}

Serum and plasma samples

Blood was drawn from the cubital vein into plastic tubes and allowed to stand for two hours at room temperature for the preparation of serum samples and about 15 minutes for the preparation of plasma samples. After centrifugation the serum fraction was separated and stored at $-20^{\circ} \mathrm{C}$ until used for analysis. Samples were taken between $8 \mathrm{a} . \mathrm{m}$. and $11 \mathrm{a} . \mathrm{m}$.

\section{Extraction and chromatographic separation}

Known quantities of $\left[{ }^{3} \mathrm{H}\right.$ ]corticosterone (about $444 \mathrm{~Bq}(12 \mathrm{nCi})$ ) and $\left[{ }^{3} \mathrm{H}\right]$ deoxycortisol (about $133 \mathrm{~Bq}(3.6 \mathrm{nCi})$ ) were mixed with a serum sample $(1-3 \mathrm{ml})$ in conical glass tubes. After extraction with $8 \dot{\mathrm{ml}}$ of dichloromethane for 10 minutes and centrifugation at $3000 \mathrm{rev} / \mathrm{min}$ the organic phases were evaporated to dryness under a stream of nitrogen at $35^{\circ} \mathrm{C}$. The residue was redissolved in $150 \mu \mathrm{l}$ of dichloromethane and chromatographed on paper in a modified Bush system, consisting of $n$-hexane/benzene/methanol/water $\left(60+40+35+65\right.$ by vol.). The $\left[{ }^{3} \mathrm{H}\right]$ corticasterone area was located on paper strips by radio scanning (Packard Instruments, model 7200$)$. As the amount of $\left[{ }^{3} \mathrm{H}\right]$ deoxycortisol was too low to be monitored, the deoxycortisol area was identified by the $R_{B}$ ratio, defined as migration of deoxycortisol/ migration of corticosterone. Migration is the distance in $\mathrm{cm}$ from the origin to the midpoint of the steroid area. This ratio $R_{B}$ was derived from standard strips which were loaded with a higher activity of each steroid (about $7400 \mathrm{~Bq}(0.2 \mu \mathrm{Ci})$ ) and developed in each chromatographic run together with the sample strips. The corticosterone and deoxycortisol areas were eluted with $3 \mathrm{ml}$ of methanol.

\section{Radioimmunoassay}

The procedure for radioimmunoassay was essentially the same for both steroids. The methanolic eluates were evaporated to dryness under a stream of nitrogen at room temperature. The residues were redissolved in borate buffer ( $1500 \mu$ l for corticosterone and $500 \mu \mathrm{l}$ for deoxycortisol). Aliquots ( $500 \mu \mathrm{l}$ for corticosterone and $200 \mu \mathrm{l}$ for deoxycortisol) were pipetted into counting vials for estimating $\left[{ }^{3} \mathrm{H}\right]$ recovery. Three $100 \mu \mathrm{l}$ aliquots representing three-fold dilution samples of the original buffer solution were used for radioimmunoassay. Standard curves were set up in triplicate. The quantities of unlabelled steroid dissolved in $100 \mu \mathrm{l}$ borate buffer ranged from 3.12 to $800 \mathrm{pg}$ in steps of two fold dilution. Competing $\left[{ }^{3} \mathrm{H}\right]$ steroid $(370 \mathrm{Bg}(10 \mathrm{nCi})$ for corticosterone and $259 \mathrm{~Bq}(7 \mathrm{nCi})$ for deoxycortisol) dissolved in $100 \mu \mathrm{l}$ borate buffer and $200 \mu \mathrm{l}$ of antiserum buffer solution were added both to the unknown and standard samples. After iñcubation at $4^{\circ} \mathrm{C}$ for $16 \mathrm{~h}$ separation of free and bound steroid was achieved using the dextran-coated charcoal method.

The radioimmunoassay data were evaluated and the standard. curves were plotted with a modular constructed computer program (6). The "spline-function"-method was used as standard curve fitting model for the standard curve (7). All operating procedures were done with an IBM-1800 computer.

\section{Results}

\section{Paper chromatography}

The chromatographic properties of the two steroids in the modified Bush system are shown in figure 1. The distance of migration after $20 \mathrm{~h}$ was about $23 \mathrm{~cm}$ for corticosterone. The $R_{B}$ ratio was found to be $1.16 \pm 0.01$ (S. D.) in 20 different assays.

\section{Antisera}

Table 1 demonstrates the physicochemical parameters of the corticosterone- and deoxycortisol-antibody reactions. 


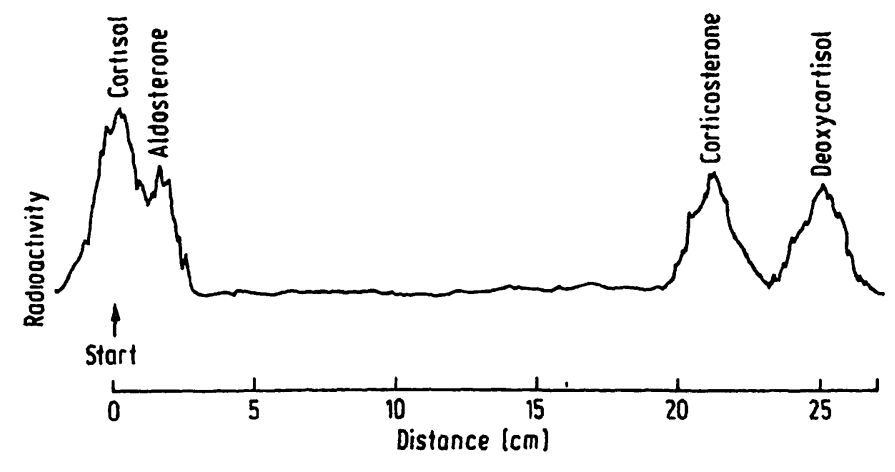

Fig. 1. Radiochromatogram of a steroid paper chromatography. System: $\mathrm{n}$-hexane/benzenè/methanol/water $(60+40+35+65$ by vol.). Time of equilibration: 20 hours. Time of chromatography: 20 hours.

Tab. 1. Physicochemical parameters of steroid-antibody complexes.

\begin{tabular}{|c|c|c|c|c|c|c|}
\hline Steroid & $\begin{array}{l}\text { Mean } \\
\text { Affinity } \\
\text { Constant } \\
{[1 / \mathrm{mol}]}\end{array}$ & $\begin{array}{l}\text { Capacity } \\
\text { of } \\
\text { Binding } \\
\text { Equi- } \\
\text { valents } \\
\text { [mol/1] }\end{array}$ & $\begin{array}{l}\text { Dissociati } \\
{\left[\mathrm{s}^{-1}\right]} \\
\mathrm{r}_{1}\end{array}$ & $\begin{array}{l}\text { ion Rate } \\
\mathbf{r}_{2}\end{array}$ & $\begin{array}{l}\text { Half-L } \\
\text { Time } \\
{[\mathrm{min}]} \\
\tau^{1} \\
1 / 2\end{array}$ & $\begin{array}{l}\text { Life } \\
\begin{array}{l}\tau^{2} \\
1 / 2\end{array}\end{array}$ \\
\hline $\begin{array}{l}\text { Cortico- } \\
\text { sterone }\end{array}$ & $2.9 \cdot 10^{9}$ & $2.3 \cdot 10^{-6}$ & $5.2 \cdot 10^{-4}$ & $3.8 \cdot 10^{-5}$ & 22 & 300 \\
\hline $\begin{array}{l}\text { Deoxy- } \\
\text { cortisol }\end{array}$ & $3.3 \cdot 10^{9}$ & $1.6 \cdot 10^{-5}$ & $6.3 \cdot 10^{-4}$ & $6.5 \cdot 10^{-5}$ & 18 & 177 \\
\hline
\end{tabular}

Equilibrium constants as well as binding capacities were determined by antibody saturation. The resulting saturation curves were evaluated by a Scatchard plot.

Rates of dissociation of the ${ }^{3} \mathrm{H}$-labelled steroid-antibodycomplexes at $4{ }^{\circ} \mathrm{C}$ were determined by preincubation for $20 \mathrm{~h}$ followed by the addition of $4000 \mathrm{pg}$ of unlabelled steroid. ${ }^{3} \mathrm{H}$-measurement of the supernatant as a function of time permitted the estimation of the dissociation rate. The semilogarithmic plot of the dissociation of both steroid complexes yielded a curve indicating the existence of at least two antibody species with different physicochemical behaviour. The values of the two different rates were obtained by extrapolation of the two asymptotes of the hyperbolic curve.

\section{Standard curve parameters}

Figure 2 represents the computer plots of a standard curve for corticosterone and deoxy cortisol, respectively. The mean sensitivites ( 2 standard deviations of the zero point) were $5.8 \pm 3.7$ (S. D.) $\mathrm{pg}$ for corticosterone and $7.4 \pm 9.2$ (S. D.) pg for deoxycortisol. These values corresponded to $59 \mathrm{ng} / 1$ for corticosterone and to $25 \mathrm{ng} / 1$ for deoxycortisol if $3 \mathrm{ml}$ of serum were used. The amount of unlabelled steroid displacing $50 \%$ of the labelled steroid from the antibody was $111.4 \pm 15.7$

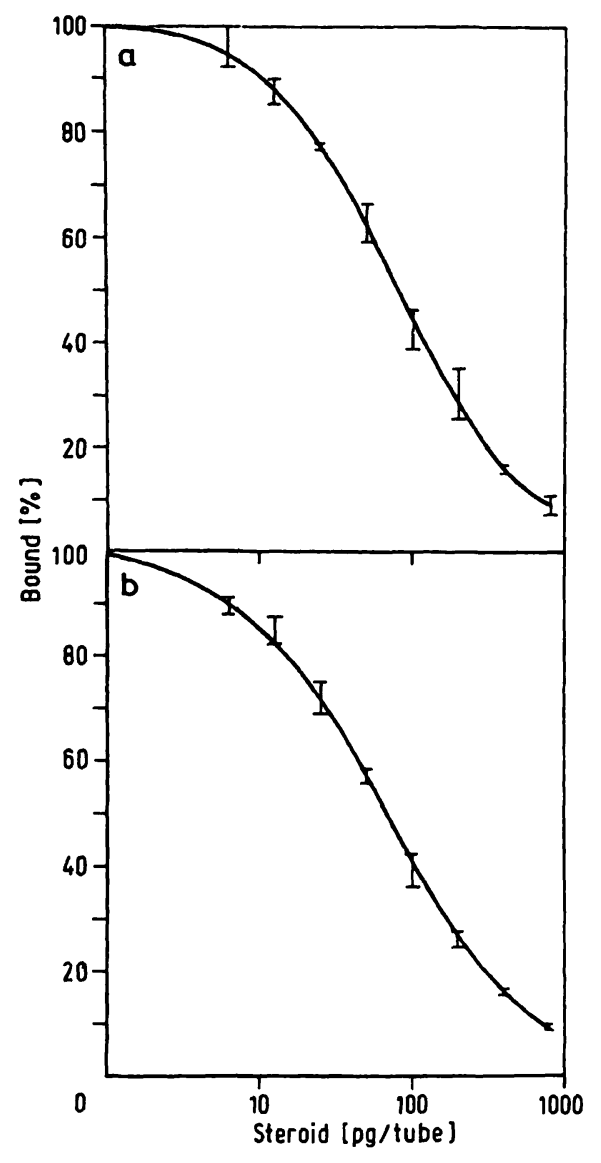

Fig. 2. Representative standard curves of corticosterone (a) and deoxycortisol (b) radioimmunoassay. Calculation and plotting was done by the "spline-function"-model (7).

(S. D.) pg for corticosterone and $92.4 \pm 11.8$ (S. D.) $\mathrm{pg}$ for deoxycortisol, corresponding to $1142 \mathrm{ng} / \mathrm{l}$ and $920 \mathrm{ng} / \mathrm{l}$, respectively, for a $3 \mathrm{ml}$ sample.

\section{Assay parameters}

The overall specificity of the present assay technique is an expression of the specificity of the antibody together with that of the chromatographic separation.

The applied chromatographic system provides a high degree of separation of corticosterone and deoxycortisol from the major $\mathrm{C}_{21}$-steroids. The cross reactions of the antibodies with certain other dihydroxylated progesterone derivatives, that exhibit chromatographic behaviour similar to that of corticosterone and deoxycortisol, were negligible (5).

Recovery of added $\left[{ }^{3} \mathrm{H}\right]$ corticosterone and $\left[{ }^{3} \mathrm{H}\right]$ deoxycortisol after chromatography averaged $65.6 \pm 10.4$ (S. D.) \% and $48.8 \pm 10.1$ (S. D.) \%, respectively.

Assay blanks were studied in distilled water and "charcoalstripped" serum. The blanks arising in $3 \mathrm{ml}$ water were $44 \pm 59$ (S. D.) $\mathrm{ng} / \mathrm{l}(\mathrm{n}=9)$ for corticosterone and $31 \pm 18$ (S. D.) $\mathrm{ng} / \mathrm{l}(\mathrm{n}=7)$ for deoxycortisol. The blank 


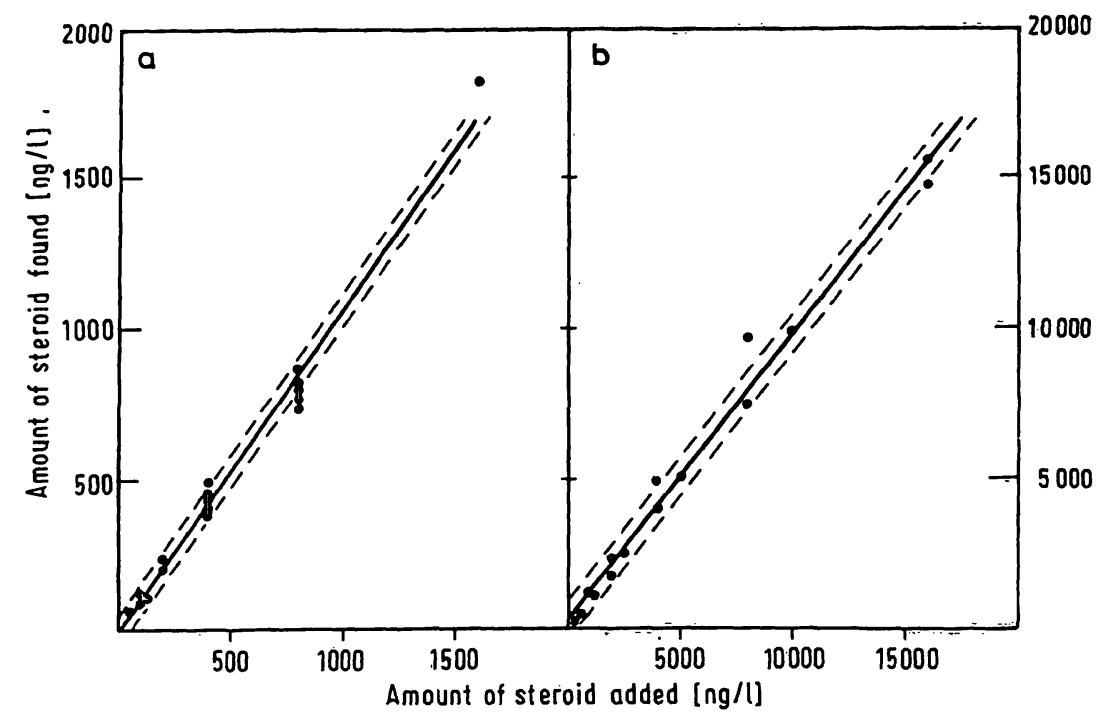

Fig. 3. Correlation between steroid amounts added and estimated. Broken lines indicate standard deviations of regression lines.

a) Deoxycortisol: equation of regression: $y=-0.6+1.07 \cdot x$; coefficient of correlation: 0.992 .

b) Corticosterone: equation of regression: $y=26.1+0.95 \cdot x$; coefficient of correlation: 0.992 .

values in $3 \mathrm{ml}$ "charcoal-stripped" serum amounted to $77.3 \pm 72$ (S. D.) $n g / l(n=14)$ for corticosterone and to $56 \pm 59$ (S. D.) $n g / 1(n=8)$ for deoxycortisol. Paper blanks were lower than the sensitivity of the standard curve.

Accuracy was studied by the estimation of added known quantities of steroid, corresponding to endogenous levels. Regression analysis for the relationship between the amounts added and measured were computed (fig. 3). The best-fit straight lines have slopes which are not significantly different from the theoretically expected ones $(b=1)$.

The intraassay and interassay variabilities of both assays at different concentration levels are shown in table 2. The concentrations studied correspond to endogenous levels. The coefficient values indicate a satisfactory precision.

Figure 4 demonstrates the correlations of steroid concentrations found in plasma and serum. The statistical
Tab. 2. Intraassay and interassay variation of corticosterone and deoxycortisol radioimmunoassay.

\begin{tabular}{|c|c|c|c|c|c|c|}
\hline \multirow[t]{2}{*}{ Steroid } & \multicolumn{3}{|c|}{ Intraassay Variation } & \multicolumn{3}{|c|}{ Interassay Variation } \\
\hline & $\begin{array}{l}\text { Mean } \\
{[\mathrm{ng} / \mathrm{l}]}\end{array}$ & $\mathbf{N}$ & $\begin{array}{l}\text { Coeffi- } \\
\text { cient of } \\
\text { Variation } \\
{[\%]}\end{array}$ & $\begin{array}{l}\text { Mean } \\
{[\mathrm{ng} / \mathrm{l}]}\end{array}$ & $\mathbf{N}$ & $\begin{array}{l}\text { Coeffi- } \\
\text { cient of } \\
\text { Variation } \\
{[\%]}\end{array}$ \\
\hline $\begin{array}{l}\text { Cortico- } \\
\text { sterone }\end{array}$ & $\begin{array}{r}780 \\
1460 \\
5360 \\
9749 \\
12880\end{array}$ & $\begin{array}{l}12 \\
11 \\
10 \\
11 \\
11\end{array}$ & $\begin{array}{r}12.9 \\
10.0 \\
9.0 \\
14.9 \\
10.2\end{array}$ & $\begin{array}{r}680 \\
1290 \\
5080 \\
10190\end{array}$ & $\begin{array}{r}10 \\
9 \\
6 \\
9\end{array}$ & $\begin{array}{r}13.9 \\
10.6 \\
9.4 \\
13.0\end{array}$ \\
\hline $\begin{array}{l}\text { Deoxy- } \\
\text { cortisol }\end{array}$ & $\begin{array}{r}172 \\
340 \\
377 \\
587 \\
1397\end{array}$ & $\begin{array}{r}9 \\
5 \\
10 \\
10 \\
10\end{array}$ & \begin{tabular}{r|}
11.8 \\
11.0 \\
8.6 \\
8.3 \\
9.7
\end{tabular} & $\begin{array}{l}194 \\
467 \\
838\end{array}$ & $\begin{array}{l}7 \\
7 \\
5\end{array}$ & $\begin{array}{r}7.6 \\
18.4 \\
15.9\end{array}$ \\
\hline
\end{tabular}

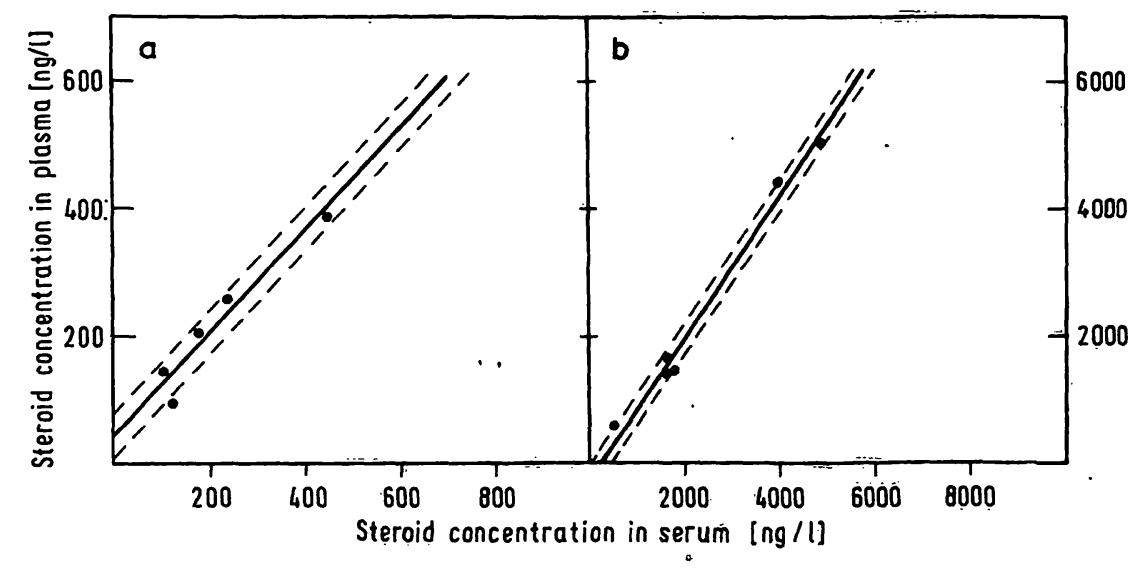

Fig. 4. Correlation between serum and plasma concentrations for deoxycortisol (a) and cortiçosterone (b). Broken lines indiçate standard deviations of regression lines. Equation of regression: $y=3.7+0.81 \cdot x$ for deoxycortisol and $Y=-21.8+1.1 \cdot x$ for corticosterone. Coefficients of correlation: 0.964 for deoxycortisol and 0.99 .3 for corticosterone. 
evaluation exhibited no significant difference between plasma and serum concentrations both of corticosterone and deoxycortisol.

\section{Normal values}

The serum concentrations of corticosterone and deoxycortisol were measured in a series of normal males, and in normal females in the follicular and luteal phase. All the females studied had a normal menstrual cycle. The mean concentration, number of subjects studied and range of each group as well as statistical values of comparison are demonstrated in table 3.

Tab. 3. Normal serum concentrations of corticosterone and deoxycortisol in normal subjects and statistical comparison of mean values. NS = not significant.

\begin{tabular}{|c|c|c|c|c|}
\hline Steroid & & $\begin{array}{l}\text { Males } \\
\delta\end{array}$ & $\begin{array}{l}\text { Females } \\
\text { (follicular) } \\
\text { \& F }\end{array}$ & $\begin{array}{l}\text { Females } \\
\text { (luteal) } \\
\& \mathrm{~L}\end{array}$ \\
\hline \multirow[t]{2}{*}{$\begin{array}{l}\text { Cortico- } \\
\text { sterone }\end{array}$} & $\begin{array}{l}\text { Mean [ng/l] } \\
N \\
\text { range [ng/l] }\end{array}$ & $\begin{array}{l}4210 \\
31 \\
850-9150\end{array}$ & $\begin{array}{l}2410 \\
16 \\
575-5400\end{array}$ & $\begin{array}{l}4390 \\
15 \\
1750-10270\end{array}$ \\
\hline & \multicolumn{2}{|c|}{ Comparison: $\begin{array}{r}\delta-9 F \\
\delta-9 L \\
Q F-9 L\end{array}$} & $\begin{array}{l}p<0.01 \\
\text { NS } \\
p<0.01\end{array}$ & \\
\hline \multirow[t]{2}{*}{$\begin{array}{l}\text { Deoxy- } \\
\text { cortisol }\end{array}$} & $\begin{array}{l}\text { Mean [ng/l] } \\
\mathrm{N} \\
\text { range [ng/l] }\end{array}$ & $\begin{array}{l}499 \\
18 \\
152-1036\end{array}$ & $\begin{array}{l}207 \\
14 \\
46-504\end{array}$ & $\begin{array}{l}335 \\
12 \\
137-734\end{array}$ \\
\hline & \multicolumn{2}{|c|}{ Comparison: $\begin{array}{r}\delta-9 F \\
\delta-9 L \\
Q F-Q L\end{array}$} & $\begin{array}{l}p<0.002 \\
\text { NS } \\
\text { NS }\end{array}$ & \\
\hline
\end{tabular}

Significant differences between males and females in the follicular phase were found for both steroids, while differences between males and females in the luteal phase were not significant. Mean serum concentrations were significantly different between females in the follicular phase and females in the luteal phase for corticosterone, but the corresponding mean values for deoxycortisol were not significantly different.

\section{Changes after stimulation and suppression of adrenal cortex}

Corticotropin was administered to normal subjects between 8 a. $m$. and 9 a. m.. Figure 5 shows a marked in crease of both steroids. After $90 \mathrm{~min}$, the mean level of 5 subjects rose from $4060 \mathrm{ng} / 1$ to $31440 \mathrm{ng} / \mathrm{l}$ for corticosterone and from $970 \mathrm{ng} / \mathrm{l}$ to $3596 \mathrm{ng} / \mathrm{l}$ for deoxycortisol. The percentage increase of serum corticosterone was significantly higher than that of deoxycortisol $(\mathrm{p}<0.05)$. The effects of insulin-induced hypoglycemia on serum corticosterone and deoxycortisol were studied in normal subjectš. Figure 6 demonstrates the considerable increase of both steroids, which begins after about $30 \mathrm{~min}$. In

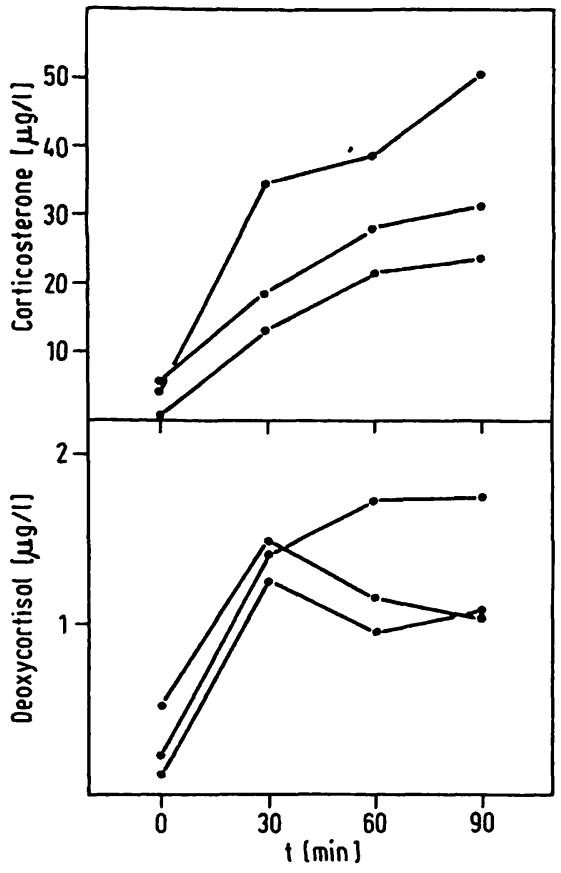

Fig. 5. Changes in serum concentrations of corticosterone and deoxycortisol after i. v. injection of $250 \mu \mathrm{g}$ corticotropin between $8 \mathrm{a}$. m. and 9 a. $\mathrm{m}$.

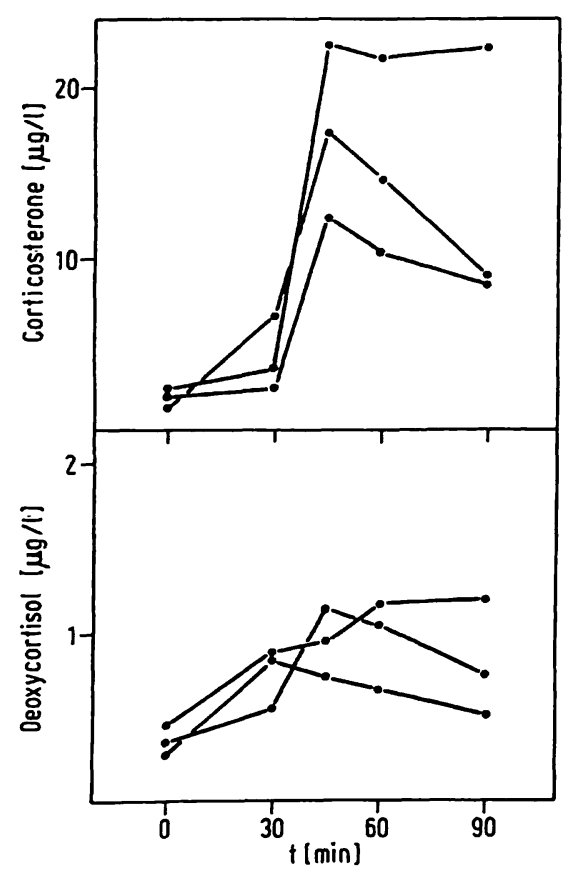

Fig. 6. Changes in serum concentrations of corticosterone and deoxycortisol after i. v. injection of $0.1 \mathrm{IE} / \mathrm{kg}$ body weight of insulin between $8 \mathrm{a}$. $\mathrm{m}$. and $9 \mathrm{a}$. $\mathrm{m}$.

6 subjects, mean serum corticosterone rose from 2060 $\mathrm{ng} / \mathrm{l}$ to $19535 \mathrm{ng} / \mathrm{l}$ after $90 \mathrm{~min}$ and mean serum deoxycortisol rose from $570 \mathrm{ng} / \mathrm{l}$ to $2063 \mathrm{ng} / \mathrm{l}$ after $90 \mathrm{~min}$. As in the corticotropin stimulation, the percentage increase of corticosterone was significantly higher than that of deoxycortisol $(p<0.01)$. Figure 7 shows the 


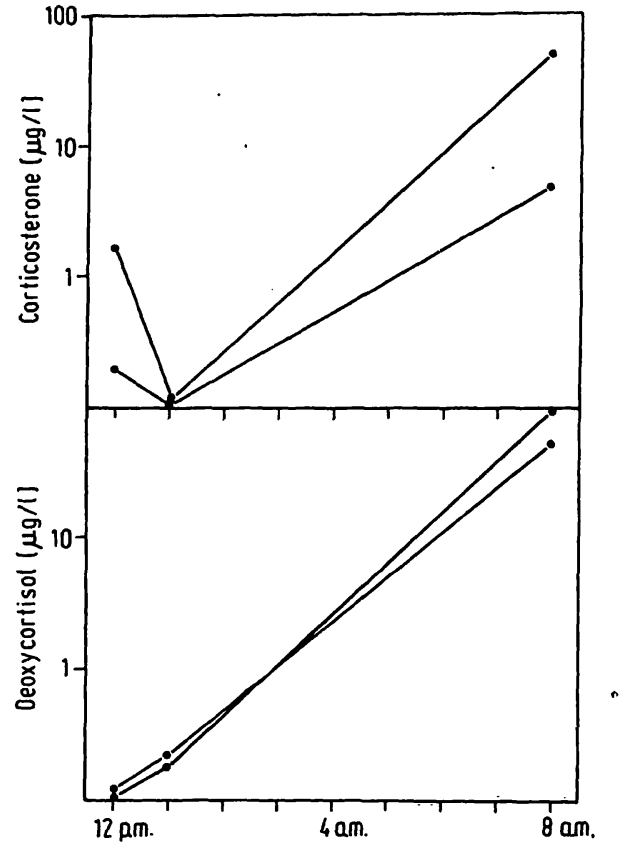

Fig. 7. Serum concentrations of corticosterone and deoxycortisol before and after oral administration of $30 \mathrm{mg} /$ $\mathrm{kg}$ of metyrapone at midnight.

changes of serum corticosterone and deoxycortisol after oral administration of metyrapone at midnight. One $\mathrm{h}$ after administration, serum deoxycortisol increased slightly, while serum corticosterone decreased to the level of the detection limit. These changes are caused by the inhibition of 11-hydroxylase due to metyrapone. Up to $8 \mathrm{a}$. $\mathrm{m}$. deoxycortisol increased markedly, and corticosterone rose to levels slightly higher than the upper end of the normal range, although enzyme blockade obviously was still effective.

Figure 8 shows changes of serum corticosterone and deoxycortisol before and after oral administration of $1 \mathrm{mg}$ dexamethasone. Mean serum concentrations of both steroids decreased below the lower limit of the normal range.

\section{Discussion}

A radioimmunoassay procedure has been described for the simultaneous measurement of the serum concentrations of corticosterone and deoxycortisol. A few methods have been published for the simultaneous estimation of these two steroids (1-4), but in no procedure paper chromatography was used for the separation which is necessary for every simultaneous steroid assessment. Paper chromatography was preferred to other techniques, because paper can be easily and reliably cleaned by solvent extraction, overnight development can be used and positive location of each sample is simple and non-destructive if radioactive tracer is included.

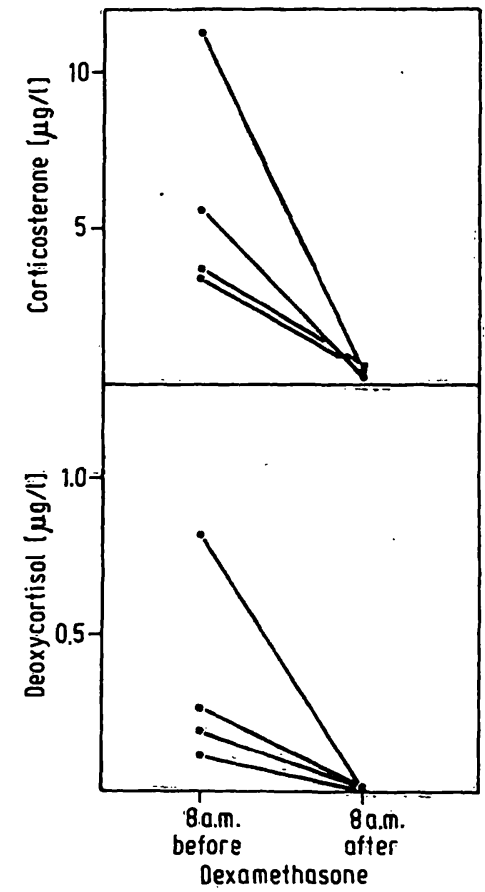

Fig. 8. Serum concentrations of corticosterone and deoxycortisol before and after oral administration of $1 \mathrm{mg}$ dexamethasone.

Recently, Mason et al. (1) demonstrated that corticosterone and deoxycortisol are difficult to separate by means of paper chromatography in the commonly used Bush systems. The use of a more polar stationary phase, as described here, provides a sufficient separation and abolishes further purification steps. The use of solvents purified by charcoal and of paper strips intensively washed with methanol eliminated the assay blanks nearly quantitatively as demonstrated by the blank studies in distilled water and on paper. The very low steroid amounts found in "charcoal-stripped" serum probably were due to insufficient stripping procedures.

Accuracy and precision of the method have proved to be adequate and similar to those commonly achieved in radioimmunoassays of individual steroids.

The normal ranges for serum concentrations of corticosterone shown in table 3 are similar to those reported in the literature (1-4, 8-13). Sex differences in serum corticosterone have been reported by West et al. (13), who found higher values in females $(6550 \mathrm{ng} / \mathrm{l})$ than in males $(3960 \mathrm{ng} / \mathrm{l})$. These results cannot be supported by the present study. This discrepancy may be explained by the well-known great variability of corticosterone serum concentrations due to episodic secretion and sensitive dependence on stress. The normal range of serum deoxycortisol concentrations measured by the present method is the lowest hitherto reported in the literature (tab. 4). Only Oddi et al. (3) using a double isotope derivative dilution technique reported comparable values (mean serum deoxycortisol: $600 \pm 500 \mathrm{ng} / \mathrm{l}$ ). Using an individual radioimmunoasșay for serum deoxy- 
Tab. 4. Comparison of plasma or serum deoxycortisol in normal subjects determined by different methods and authors. $\mathbf{P}=$ plasma; $\mathbf{S}=$ serum; $\mathrm{DID}=$ double isotope dilution; GLC = gas-liquid chromatography; $C P B=$ competitive protein binding; $P S R=$ Porter Silber reaction; RIA = radioimmunoassay;

\begin{tabular}{llllll}
\hline Reference & $\begin{array}{l}\text { Me- } \\
\text { thod }\end{array}$ & $\mathrm{N}$ & $\begin{array}{l}\text { Mean } \pm \text { S.D. } \\
{[\mu \mathrm{g} / \mathrm{l}]}\end{array}$ & $\begin{array}{l}\text { Ma- } \\
\text { terial }\end{array}$ & $\begin{array}{l}\text { Range } \\
{[\mu \mathrm{g} / \mathrm{ll}]}\end{array}$ \\
\hline Mason (1) & GLC & 4 & $\mathrm{P}$ & $0.4-4.0$ \\
Newsome (2) & CC & 1.8 & $\mathrm{P}$ & \\
Oddie (3) & DID & 16 & 0.6 & $\mathrm{P}$ & $0-20$ \\
Kolanowski (4) & CPB & 34 & 1.1 & $\mathrm{P}$ & \\
Spark (14) & CPB & & 8.0 & $\mathrm{P}$ & \\
Jubiz (15) & CPB & & 10.0 & $\mathrm{P}$ & \\
Waxmann (16) & PSR & 2.0 & $\mathrm{P}$ & \\
Vielhauer (17) & RIA & & 1.41 & $\mathrm{P}$ & \\
Lee (18) & RIA & & 8.0 & $\mathrm{P}$ & $5.6-13.8$ \\
Mahajan (19)*) & RIA & & 2.0 & $\mathrm{P}$ & \\
Present study & RIA & 18 & $0.49 \circ$ & $\mathrm{S}$ & $0.15-1.0$ \\
& & 26 & 0.27 8**) & $\mathrm{S}$ & $0.09-0.6$ \\
\hline
\end{tabular}

*) Dexamethasone suppressed.

**) Values represent the mean of females in the follicular and luteal phase.

cortisol without chromatographic purification, we found a mean deoxycortisol concentration of $1540 \pm 935$ (S. D.) $\mathrm{ng} / \mathrm{l}$ in a series of 24 normal males and 17 normal females. This value is similar to the mean concentration of $1410 \mathrm{ng} / \mathrm{l}$ reported by Vielhauer et al. (17), who used the same antibody in a radioimmunological method without chromatography. This indicates that the higher normal serum deoxycortisol concentrations may represent over-estimations probably due to blanks or cross reacting compounds. Sex differences in deoxycortisol have not been hitherto reported. In the present study, mean deoxycortisol values were found to be nearly two-fold higher in males than in females in the follicular phase. This sex difference is in agreement with those of other corticotropin regulated adrenocortical steroids, such as cortisol (20), deoxycorticosterone (21) or corticosterone (present study).

Adrenal stimulation by corticotropin itself or by insulininduced hypoglycemia caused a marked increase of serum concentrations of corticosterone and deoxycortisol. This is explained by the pituitary control of the adrenocortical secretion of these steroids. It is of interest that the increase of corticosterone concentration is significantly greater than that of deoxycortisol. A similar relation has already been observed between corticosterone and cortisol after adrenocortical stimulation (4). Obviously, the secretion profile of deoxycortisol is more correlated to that of cortisol than to that of corticosterone.

The decrease of serum corticosterone and the increase of serum deoxycortisol one hour after metyrapone administration is quite well explained by the inhibition of the 11-hydroxylase. The marked increase of corticosterone 8 hours after metyrapone is not easily understandable. Probably, it is caused by an increasing insufficiency of enzyme blockade.

\section{Acknowledgements}

We are indebted to Prof. Dr. W. Oelkers for constructive discussion, and to Prof. Dr. P. Koeppe, Klinikum Steglitz, for providing computer facilities in the Department of Radiology and Nuclear Medicine.

\section{References}

1. Mason, P. A. \& Fraser, R. (1975), J. Endocrinol. 64, $277-288$.

2. Newsome, H., Clements, A. S. \& Borum, E. H. (1972), J. Clin. Endocrinol. Metab. 34, 473-483.

3. Oddie, C. J., Coghlan, J. P. \& Scoggins, B. A. (1972), J. Clin. Endocrinol. Metab. 34, 1039-1054.

4. Kolanowski, J. (1974), J. Steroid Biochem. 5, 55-64.

5. Vecsei, P. (1974), "Glucocorticoids: Cortisol, corticosterone, and compound S", Chapter 23 in Methods of Hormone Radioimmunoassay, Eds. Jaffe, E. M. \& Behrman, H. R., Academic Press, New York.

6. Schöneshöfer, M. (1975), Acta Endocrinol. (Copenhagen), Suppl. 193, 116.

7. Marschner, I., Ėrhardt, F. W. \& Scriba, P. C. (1974), in: Radioimmunoassay and related procedures in medicine, Vol. 1, p. 111-122. Proceedings, Symposium Istanbul, Internat. Atomic Energy Agency, Vienna.

8. Fraser, R. \& James, V. H. T. (1968), J. Endocrinol. $40,59-72$.

9. Nabors, C. J., West, C. D., Mahajan, D. K. \& Tyler, F. H. (1974), Steroids 23, 363-378.

10. Underwood, R. H. \& Williams, G. H. (1972), J. Lab. Clin. Med. 79, 848-862.

11. Peterson, R. E., Pierce, C. E. (1960), J. Clin. Invest. 39, 741-75.
12. Hamanaka, Y., Manabe, H., Tanaka, H., Monden, Y., Kozumi, T. \& Matsumoto, K. (1970), Acta Endocrinol. (Copenhagen) 64, 439-445.

13. West, C. D., Mahajan, D. K., Chavré, V. J., Nabors, C. J. \& Tyler, F. H. (1973), J. Clin. Endocrinol. Metab. 36, 1230-1236.

14. Spark, R. F. (1971), Ann. Int. Med. 75, 717-723.

15. Jubiz, W., Matsukura, S., Meikle, A. W., Havada, G., West, C. D. \& Tyler, F. H. (1970), Archs. Intern. Med. 125, 468-471 (1969).

16. Waxmann, S. H., Tippit, D. F. \& Kelley, V. C. (1961), J. Clin. Endocrinol. Metab. 21, 943-954.

17. Vielhauer, V., Gless, K. H. \& Vecsei, P. (1974), Acta Endocrinol. (Copenhagen), Suppl. 184, 65.

18. Lee, L. M. Y. \& Schiller, H. S. (1975), Clin. Chem. 21, 719-724.

19. Mahajan, D. K., Wahlen, J. D., Tyler, F. H. \& West, C. D. (1972), Steroids 20,609-620.

20. Zumoff, B., Fukushima, D. K., Weitzman, E. D., Kream, J. \& Hellman, L. (1974), J. Clin. Endocrinol. Metab. 39, $805-808$.

21. Schöneshöfer, M., Oelkers, W. \& Harendt, H. (1975), this j. $13,143-147$

Dr. M. Schöneshöfer Klinikum Steglitz

Medizinische Klinik und Poliklinik

Abteilung Endokrinologie

Hindenburgdamm 30

D-1000 Berlin 45 
.<smiles>[Mg]</smiles> 